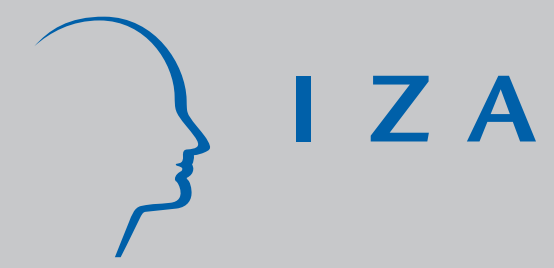

IZA DP No. 829

Selection Bias, Comparative Advantage and Heterogeneous Returns to Education: Evidence from China in $\mathbf{2 0 0 0}$

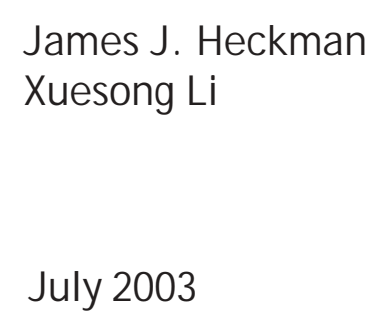

J uly 2003 


\title{
Selection Bias, Comparative Advantage and Heterogeneous Returns to Education: Evidence from China in 2000
}

\author{
James J. Heckman \\ University of Chicago, American Bar Foundation \\ and IZA Bonn \\ Xuesong Li \\ Chinese Academy of Social Sciences
}

\author{
Discussion Paper No. 829 \\ July 2003
}

IZA

P.O. Box 7240

D-53072 Bonn

Germany

Tel.: +49-228-3894-0

Fax: +49-228-3894-210

Email: iza@iza.org

\begin{abstract}
This Discussion Paper is issued within the framework of IZA's research area Evaluation of Labor Market Policies and Projects. Any opinions expressed here are those of the author(s) and not those of the institute. Research disseminated by IZA may include views on policy, but the institute itself takes no institutional policy positions.

The Institute for the Study of Labor (IZA) in Bonn is a local and virtual international research center and a place of communication between science, politics and business. IZA is an independent, nonprofit limited liability company (Gesellschaft mit beschränkter Haftung) supported by Deutsche Post World Net. The center is associated with the University of Bonn and offers a stimulating research environment through its research networks, research support, and visitors and doctoral programs. IZA engages in (i) original and internationally competitive research in all fields of labor economics, (ii) development of policy concepts, and (iii) dissemination of research results and concepts to the interested public. The current research program deals with (1) mobility and flexibility of labor, (2) internationalization of labor markets, (3) welfare state and labor market, (4) labor markets in transition countries, (5) the future of labor, (6) evaluation of labor market policies and projects and (7) general labor economics.
\end{abstract}

IZA Discussion Papers often represent preliminary work and are circulated to encourage discussion. Citation of such a paper should account for its provisional character. A revised version may be available on the IZA website (www.iza.org) or directly from the author. 
IZA Discussion Paper No. 829

July 2003

\section{ABSTRACT \\ Selection Bias, Comparative Advantage and Heterogeneous Returns to Education: Evidence from China in 2000*}

This paper uses newly available Chinese micro data to estimate the return to college education for late $20^{\text {th }}$ century China when allowing for heterogeneous returns among individuals selecting into schooling based on these differences. We use recently developed semiparametric methods to identify the parameters of interest. We demonstrate that heterogeneity among people in returns to schooling is substantial. People sort into schooling on the basis of the principle of comparative advantage, which we document to be an empirically important phenomenon in modern Chinese labor markets. Standard least squares or instrumental variable methods do not properly account for this sorting. Using new methods that do, we estimate the effect on earnings of sending a randomly selected person to college is a $43 \%$ increase in lifetime earnings (nearly $11 \%$ annually) in 2000 for young people in urban areas of six provinces of China. The effect of college on those who go is $13 \%$. Our evidence, and simple least squares evidence, suggests that after 20-plus years of economic reform with market orientation, the return to education has increased substantially in China, compared to the returns measured in the 1980's and the early 1990's.

JEL Classification: C31

Keywords: $\quad$ education, returns to education

Corresponding author:

James J. Heckman

Department of Economics

University of Chicago

1126 East $59^{\text {th }}$ Street

Chicago, IL 60637

USA

Tel.: +17737020634

Fax: +17737028490

Email: jjh@uchicago.edu

\footnotetext{
* We thank Salvador Navarro-Lozano for his help with the program used in this work. We thank Leslie Cooke for research assistance. We thank Pedro Carneiro, Edward Vytlacil and Junsen Zhang for their helpful comments.
} 


\section{Introduction}

Heterogeneity and missing counterfactual states are central features of microdata. Due to unobserved heterogeneity, observationally identical people make different choices, earn different wages and hold different levels and compositions of asset portfolios. The evaluation problem for social programs arises from a missing data problem. We cannot observe the outcomes of all possible choices for the same person. If we observe wages for college graduates, we cannot observe the wages they would have earned if they had been high school graduates.

Conventional approaches to selection and missing data problems do not account for heterogeneity in responses to schooling on which agents select into schooling. This paper uses newly released cross-sectional micro data from the China Urban Household Investment and Expenditure Survey (CUHIES 2000), to estimate the return to education for China when responses to schooling differ among individuals and individuals select into schooling based their idiosyncratic returns. Our work draws on previous research by Heckman and Vytlacil (1999, 2000, 2001), Carneiro, Heckman and Vytlacil (2001) and Carneiro (2002), which develops a semiparametric framework that accounts for heterogeneity and selection. ${ }^{1}$

Our results reveal that the average treatment effect $(A T E)$ of four year college attendance (the earnings gain arising from randomly selecting someone to go to college for four years), is $43 \%$ (the annual return is $10.8 \%$ ) in 2000 for young people in urban areas of six provinces of China, whereas the OLS (Ordinary Least Squares) and $I V$ (Instrumental Variables) estimators give 29\% and 56\% respectively (with estimated annual returns of $7.25 \%$ and $14 \%$ respectively). Heterogeneity in returns is substantial in the population. Estimated selection bias is an empirically important negative 22\%. Like Carneiro, Heckman and Vytlacil (2001), we find that there is comparative advantage in the labor market for schooling. The best college graduates are among the worst high school graduates. $O L S$ gives a downward-biased estimate of $A T E . I V$ produces an upward biased estimate of ATE .

${ }^{1}$ The MTE is the central concept in this literature. It was introduced by Bjorklund and Moffitt (1987). The marginal treatment effect is the average return to schooling for persons indifferent to going on to schooling at different levels of unobservable factors that determine schooling choices. Heckman and Vytlacil (1999, 2000, 2001) show that all conventional treatment parameters are different weighted averages of this parameter. 
After more than twenty years of economic reform with market orientation, the average return to education in China measured by $O L S$ or $A T E$ has increased markedly when compared to those in the 1980's and early 1990's. (Chow 2001 presents estimates of $O L S$-generated rates of return in this period). Education markets have begun to function effectively in China, and skills are now being rewarded more adequately than they have been in the past.

The paper is organized in the following way. Section 2 describes earnings models with and without heterogeneous returns to education. Section 3 defines selection bias, defines the marginal treatment effect and presents a semiparametric method for estimating it. Section 4 discusses our data and presents empirical results for China. Section 5 concludes.

\section{Models with and without Heterogeneity}

We first consider a conventional model of the return to education without heterogeneity in returns. We write the following common coefficient Mincer model:

$$
\ln Y_{i}=\beta S_{i}+\gamma X_{i}+U_{i}
$$

where $i$ is a subscript for individuals $(i=1,2, \cdots, \mathrm{n}), \ln Y_{i}$ is $\log$ income, $S_{i}$ is schooling level or years of schooling, $X_{i}$ is a vector of variables such as an intercept, years of Mincer experience, Mincer experience squared, and dummy variables for sex, region, sector, and ownership of firm. $U_{i}$ is the residual term with $E\left(U_{i}\right)=0, \beta$ is the rate of return to education, and $\gamma$ is a vector of coefficients.

One problem with $O L S$ (Ordinary Least Squares) estimates of Equation (1) is that there may be an omitted ability $A_{i}$, which is in the residual term $U_{i}$. Many empirical analysts suspect that $\operatorname{Cov}\left(A_{i}, S_{i}\right) \neq 0$ so that $E\left(U_{i} \mid S_{i}\right) \neq 0$ and $O L S$ gives biased and inconsistent estimates (Griliches, 1977 is a classic statement of this problem). ${ }^{2}$

\footnotetext{
${ }^{2}$ Most data sets do not contain measures of ability. Economists use three strategies to eliminate or attenuate the ability bias. A huge literature uses instrumental variables $(I V)$. The goal of this literature is to find an instrument $I_{i}$ that is highly correlated with $S_{i}$ but not correlated with $U_{i}$. The second approach uses the fixed effect method: find a paired comparison
} 
The specification we consider is more general than the model (1). We estimate a model with heterogeneous returns to education, which may be written in random coefficient form as

$$
\ln Y_{i}=\beta_{i} S_{i}+\gamma X_{i}+U_{i}
$$

where $\beta_{i}$ is the heterogeneous rate of return to education, which varies among individuals. $X_{i}$ is a vector of conditioning variables defined below. This model accounts for ability bias in a more general setting.

In this paper we focus on two schooling choices: high school and college. We let $S_{i}=1$ denote four-year college graduates and $S_{i}=0$ for senior high school graduates (those not going to college). Clearly, there are more choices of schooling and our analysis is a simplification of reality, but is a natural starting point with ample precedents in the literature. There is considerable evidence in many contexts that returns to schooling are nonlinear in years of schooling so conventional log wage on years of schooling regression coefficients generate rates of return that are badly biased estimates of the return to college education. (Heckman, Lochner and Todd, 2003).

The two potential selection outcomes $\left(\ln Y_{0 i}, \ln Y_{1 i}\right)$ can be written as

$$
\left\{\begin{array}{lll}
\ln Y_{0 i}=\gamma_{0} X_{i}+U_{0 i} & \text { if } & S_{i}=0 \\
\ln Y_{1 i}=\gamma_{1} X_{i}+U_{1 i} & \text { if } & S_{i}=1
\end{array}\right.
$$

where $E\left(U_{0 i} \mid X_{i}\right)=0$ and $E\left(U_{1 i} \mid X_{i}\right)=0$ in the population. In the notation of equation (2), observed log earnings $Y_{i}=S_{i} \ln Y_{i}+\left(1-S_{i}\right) \ln Y_{0 i}$ and $U_{i}=S_{i} U_{1 i}+\left(1-S_{i}\right) U_{0 i}$

such as a genetic twin or sibling with similar or identical ability. A third approach is to use proxy variables for ability and include them as regressors in $X_{i}$.

Many data sets do not have enough information to use the fixed effect method, and the method is critically dependent on additive separability of errors. Such comparisons may exacerbate measurement error problems. It is also very hard to find satisfactory instruments. In fact, most commonly used instruments in the schooling literature are invalid because they are correlated with the omitted ability. (See Carneiro and Heckman, 2002 and Carneiro, 2002).

An alternative method uses proxies for ability and includes them as the regressors. Many empirical analyses reveal that better family background and better family resources are usually associated with better environments that raise ability (Carneiro and Heckman, 2003). We use parental income as a proxy for ability in our empirical work. 
In a cross section it is usually impossible to know both $\ln Y_{0 i}$ and $\ln Y_{1 i}$ for anyone due to a fundamental missing data problem. For those going to college, we cannot observe $\ln Y_{0 i}$; for those not going to college, we cannot observe $\ln Y_{1 i}$. So we can only determine the distributions $F\left(\ln Y_{0 i} \mid X_{i}, S_{i}=0\right)$ and $F\left(\ln Y_{1 i} \mid X_{i}, S_{i}=1\right)$ but not $F\left(\ln Y_{0 i} \mid X_{i}\right)$ or $F\left(\ln Y_{1 i} \mid X_{i}\right)$. In the presence of heterogeneity and selection in general, we can no longer use conventional methods like $O L S$ or Instrumental Variables (IV) to identify economically interesting parameters.

\section{Collecting results}

$$
\begin{aligned}
\ln Y_{i} & =S_{i} \ln Y_{1 i}+\left(1-S_{i}\right) \ln Y_{0 i} \\
& =\left[\left(\gamma_{1}-\gamma_{0}\right) X_{i}\right] S_{i}+\gamma_{0} X_{i}+\left[U_{0 i}+\left(U_{1 i}-U_{0 i}\right) S_{i}\right] \\
& =\left[\left(\gamma_{1}-\gamma_{0}\right) X_{i}+\left(U_{1 i}-U_{0 i}\right)\right] S_{i}+\gamma_{0} X_{i}+U_{0 i} \\
& =\beta_{i} S_{i}+\gamma_{0} X_{i}+U_{0 i}
\end{aligned}
$$

where

$$
\beta_{i}=\left(\gamma_{1}-\gamma_{0}\right) X_{i}+\left(U_{1 i}-U_{0 i}\right)
$$

is the heterogeneous return to education for individual $i$. When $\gamma_{1} \neq \gamma_{0}$ (i.e. there is an observed heterogeneity term $\left.\left(\gamma_{1}-\gamma_{0}\right) X_{i}\right)$, or $U_{1 i} \neq U_{0 i}$ (i.e. there is an unobserved heterogeneity term $\left.\left(U_{1 i}-U_{0 i}\right)\right)$, $\beta_{i}$ varies in the population, the return to schooling is a random variable with a distribution. In the first case where we condition on $X$, the distribution of returns is degenerate. In the second case it is not degenerate. The mean of $\beta_{i}$ given $X$ is:

$$
\bar{\beta}(X)=E\left(\beta_{i} \mid X_{i}\right)=E\left[\left(\gamma_{1}-\gamma_{0}\right) X_{i}\right]
$$

Suppose individuals select going to college (or not) according to the following decision rule:

$$
\begin{array}{rlrl}
S_{i}^{*} & =P_{i}\left(Z_{i}\right)-U_{s i} \\
S_{i} & =1 & \text { if } & S_{i}^{*} \geq 0 \\
& =0 & & \text { otherwise }
\end{array}
$$

where $S_{i}^{*}$ is a latent variable denoting the net benefit of going to school and $Z_{i}$ is an observed vector of variables ( $Z_{i}$ may include some $X_{i}$ ). $P_{i}=P_{i}\left(Z_{i}\right)$ is the propensity score or probability of receiving treatment (going to college), which can be estimated by a logit or probit model. $U_{s i}$ is the unobserved heterogeneity for individual $i$ in the treatment selection equation. 
Without loss of generality we may assume that $U_{s i} \sim U n i f[0,1]$ (See Heckman and Vytlacil, 1999). The decision of whether to go to college (or not) for individual $i$ is determined completely by the comparison of the observed heterogeneity $P_{i}\left(Z_{i}\right)$ with the unobserved heterogeneity $U_{s i}$. The smaller the $U_{s i}$, the more likely the person goes to college.

\section{Selection Bias and The Marginal Treatment Effect}

Let $\Delta_{i}=\ln Y_{1 i}-\ln Y_{0 i}$ be the economic (gross) return to a policy that moves individual $i$ from $S_{i}=0$ to $S_{i}=1$. According to Equations (3a), (3b) and (5), $\Delta_{i}=\beta_{i}$, is the causal effect of education. Using equations (3a), (3b) and (6), the probability limit of the ordinary least squares estimator can be written as:

$$
\begin{aligned}
& \operatorname{plim}\left(\hat{\beta}_{O L S}\right)=E\left(\ln Y_{i} \mid X_{i}, S_{i}=1\right)-E\left(\ln Y_{i} \mid X_{i}, S_{i}=0\right) \\
& =E\left(\gamma_{1} X_{i}+U_{1 i} \mid X_{i}, S_{i}=1\right)-E\left(\gamma_{0} X_{i}+U_{0 i} \mid X_{i}, S_{i}=0\right) \\
& =\bar{\beta}(X)+\left[E\left(U_{1 i} \mid S_{i}=1\right)-E\left(U_{0 i} \mid S_{i}=0\right)\right] \\
& \text { (ATE) }
\end{aligned}
$$

where $A T E$ is the average treatment effect, (the effect of randomly assigning a person with characteristics $X$ to schooling) defined as

$$
A T E=E\left(\Delta_{i} \mid X_{i}\right)=E\left(\beta_{i} \mid X_{i}\right)=\bar{\beta}(X)
$$

If agents know and act on some components of $\left(U_{0 i}, U_{1 i}\right), S_{i}$ is generally correlated with both $U_{0 i}$ and $U_{1 i}$, and the second term in Equation (8) will be not zero, so $O L S$ is biased for $A T E$.

Note that Equation (8) can also be written as:

$$
\begin{gathered}
\operatorname{plim}\left(\hat{\beta}_{O L S}\right)=E\left(\ln Y_{i} \mid X_{i}, S_{i}=1\right)-E\left(\ln Y_{i} \mid X_{i}, S_{i}=0\right) \\
=E\left(\beta_{i} \mid X_{i}, S_{i}=1\right)+ \\
(T T) \\
{\left[E\left(U_{0 i} \mid S_{i}=1\right)-E\left(U_{0 i} \mid S_{i}=0\right)\right]}
\end{gathered}
$$

where $T T$ is treatment on the treated, the effect of treatment on those who receive it (e.g., goes to college) compared to what they would experience without treatment (i.e., do not go to college), defined as: 


$$
\begin{aligned}
T T & =E\left(\Delta_{i} \mid X_{i}, S_{i}=1\right)=E\left(\beta_{i} \mid X_{i}, S_{i}=1\right) \\
& =\bar{\beta}(X)+E\left(U_{1 i}-U_{0 i} \mid S_{i}=1\right)=A T E+E\left(U_{1 i}-U_{0 i} \mid S_{i}=1\right)
\end{aligned}
$$

(Sorting Effect)

The sorting effect $E\left(U_{1 i}-U_{0 i} \mid S_{i}=1\right)$ is the mean gain of the unobservables for people who choose "1". The selection bias $E\left(U_{0 i} \mid S_{i}=1\right)-E\left(U_{0 i} \mid S_{i}=0\right)$ is the mean difference in the no schooling ( $\left.\mathrm{S}=0\right)$ unobservables between those who go to school and those who do not. It is the difference in unobservables between what college graduates would earn if they were high school graduates and what high school graduates would earn. The bias in (8) is the sum of sorting and selection bias.

Conventional $I V$ estimators do not, in general, identify these treatment parameters in the presence of heterogeneity and selection. Finding an instrument $I_{i}$ correlated with $S_{i}$ but not $U_{0 i}$ or even $U_{1 i}-U_{0 i}$ is not enough to identify $\bar{\beta}(X)$, because:

$$
\begin{aligned}
\operatorname{plim} \hat{\beta}_{I V}= & \frac{\operatorname{Cov}\left(I_{i}, \ln Y_{i}\right)}{\operatorname{Cov}\left(I_{i}, S_{i}\right)}=\bar{\beta}(X)+\frac{\operatorname{Cov}\left(I_{i}, U_{0 i}\right)}{\operatorname{Cov}\left(I_{i}, S_{i}\right)}+\frac{\operatorname{Cov}\left[I_{i},\left(U_{1 i}-U_{0 i}\right) S_{i}\right]}{\operatorname{Cov}\left(I_{i}, S_{i}\right)} \\
& =\bar{\beta}(X)+\frac{\operatorname{Cov}\left[I_{i},\left(U_{1 i}-U_{0 i}\right) S_{i}\right]}{\operatorname{Cov}\left(I_{i}, S_{i}\right)}=\bar{\beta}(X)+\frac{\operatorname{Cov}\left[I_{i},\left(U_{1 i}-U_{0 i}\right) \mid S_{i}=1\right] P_{i}}{\operatorname{Cov}\left(I_{i}, S_{i}\right)}
\end{aligned}
$$

where $P_{i}=\operatorname{Pr}\left(S_{i}=1\right)$ is the propensity score. In the presence of both heterogeneity and selection bias, $U_{1 i} \neq U_{0 i}$, $U_{1 i}-U_{0 i}$ is dependent on $S_{i}$, so the second term in Equation (12) will be not zero, thus $\operatorname{plim}\left(\hat{\beta}_{I V}\right) \neq \bar{\beta}(X)$ so $I V$ is not a consistent estimator. Only in some very special circumstances, when $U_{1 i}-U_{0 i}=0$ (i.e. neither unobserved heterogeneity nor selection bias exist) or when $U_{1 i} \neq U_{0 i}$ but $U_{1 i}-U_{0 i}$ is independent of $S_{i}$ (i.e. there is unobserved heterogeneity but no selection bias), will the second term in Equation (12) be zero. In this case, $I V$ is a consistent estimator for $\bar{\beta}(X)$ (Heckman, 1997 and Heckman and Navarro-Lozano, 2003).

Neither $O L S$ nor $I V$ is a consistent estimator of the mean return to education in the presence of heterogeneity and selection. However, under the assumptions presented in Heckman and Vytlacil (1999, 2000, 2001), Carneiro, Heckman and Vytlacil (2001), Carneiro (2002) and Navarro-Lozano (2002), it is possible to identify the heterogeneous return to education with marginal treatment effect (MTE) via the method of Local Instrument Variables ( $L I V)$, where $M T E$ is: 


$$
\begin{aligned}
\operatorname{MTE}\left(X_{i}=x, U_{s i}=u_{s}\right)= & E\left(\Delta_{i} \mid X_{i}=x, U_{s i}=u_{s}\right)=E\left(\beta_{i} \mid X_{i}=x, U_{s i}=u_{s}\right) \\
& =\left(\gamma_{1}-\gamma_{0}\right) x+E\left(U_{1 i}-U_{0 i} \mid U_{s i}=u_{s}\right) .
\end{aligned}
$$

The MTE is the average willingness to pay $(W T P)$ for $\ln Y_{1 i}$ (compared to $\ln Y_{0 i}$ ) given characteristics $X_{i}$ and unobserved heterogeneity $U_{s i} \cdot{ }^{3}$ MTE can be estimated from the following relationship, where $L I V$ can be estimated by semiparametric methods for derivatives (see Heckman 2001):

$$
\operatorname{MTE}\left(X_{i}=x, U_{s i}=P_{i}=p\right)=\operatorname{LIV}\left(X_{i}=x, P_{i}=p\right)=\frac{\partial E\left(\ln Y_{i} \mid X_{i}=x, P_{i}=p\right)}{\partial p}
$$

For notational simplicity, we keep the conditioning on $X$ implicit in what follows.

Heckman and Vytlacil (1999, 2000, 2001) and Carneiro (2002) establish that all the other treatment variables can be unified using $M T E$

$$
\begin{array}{lr}
A T E=\int_{0}^{1} \operatorname{MTE}\left(u_{s}\right) d u_{s} & \text { (Average Treatment Effect) } \\
T T=\int_{0}^{1} \operatorname{MTE}\left(u_{s}\right) h_{T T}\left(u_{s}\right) d u_{s} & \text { (Treatment on the Treated) } \\
T U T=\int_{0}^{1} \operatorname{MTE}\left(u_{s}\right) h_{T U T}\left(u_{s}\right) d u_{s} & \text { (Treatment on the Untreated) }
\end{array}
$$

Where the weights are:

$$
\begin{aligned}
& h_{A T E}\left(u_{s}\right)=1 \\
& h_{T T}\left(u_{s}\right)=\frac{1-F_{P}\left(u_{s}\right)}{E\left(P_{i}\right)}=\frac{\int_{u_{s}}^{1} f(p) d p}{E\left(P_{i}\right)} \\
& h_{T U T}\left(u_{s}\right)=\frac{F_{P}\left(u_{s}\right)}{E\left(1-P_{i}\right)}=\frac{\int_{0}^{u_{s}} f(p) d p}{E\left(1-P_{i}\right)} .
\end{aligned}
$$

Treatment on the untreated ( TUT ) is the effect of treatment on those who do not receive it (i.e. do not go to college) compared to what they would experience with the treatment (i.e. go to college), which is defined as:

$$
\begin{aligned}
T U T= & E\left(\Delta_{i} \mid X_{i}, S_{i}=0\right)=E\left(\beta_{i} \mid X_{i}, S_{i}=0\right) \\
& =\bar{\beta}+E\left(U_{1 i}-U_{0 i} \mid S_{i}=0\right)
\end{aligned}
$$

\footnotetext{
${ }^{3} M T E$ was introduced into the literature in a parametric context by Anders Bjorklund and Robert Moffitt (1987).
} 


\section{Data Set and Empirical Results}

Our data are from the China Urban Household Income and Expenditure Survey (CUHIES) for the year 2000, which was conducted by the Urban Socio-Economic Survey Organization of the National Bureau of Statistics. The survey is a sequence of cross-sections from 1992 to 2002 and is ongoing. The urban data randomly selects households across the whole urban population.

We have the data for the year 2000 for urban areas of six provinces: Guangdong, Liaoning, Sichuan, Shaanxi, Zhejiang and Beijing. Four provinces, Guangdong, Zhejiang, Beijing and Liaoning, are located in eastern part of China, while the other two, Sichuan and Shaanxi, are in the western part. Table 1 provides the comparison of average resident income in urban areas among these provinces. The average resident incomes in the three provinces, Beijing, Guangdong and Zhejiang, are much higher than the average level of China, while they are a bit lower in the other three provinces, Sichuan, Liaoning and Shaanxi. The average income in the six provinces we use is 7627 yuan, which is higher than the average income of China, 6280 yuan.

The sample size for the six provinces is 4250 households. For each household, there is rich information on all household members, including head, spouse, children and parents. Age, sex, education level, employment status and enterprise ownership, occupation, years of work experience and total annual income are available for each household member. There are seven education levels in the sample: university, college, special technical school, senior high school, junior high school, primary school, and other.

For our purposes, we combine all the children in the six provinces who are either college or university graduates or senior high school graduates. They are all working and earn positive wages in 2000. Our sample consists of 587 individuals, including 273 people with four-year college (or university) certificates and 314 people with only senior high school certificates. There are 331 males and 256 females in the sample. The summary statistics for the variables used in our analysis are reported in Table 2, which reveals the individuals in the sample are mainly young adults with a mean age of 26.3. Thus ours is an analysis of wages early in the life cycle of new cohorts of Chinese workers.

Table 3 presents $O L S$ and $I V$ estimates of the mean return to four-year college attendance. We use the probability of going to college as the instrument with the exclusions defined below. The $O L S$ and $I V$ estimates are $29 \%$ and $56 \%$ respectively for the young people in the urban areas of six provinces of China in 2000 
(annualized $7.25 \%$ and 14\%, respectively). The $O L S$ estimates are much higher than the $O L S$ estimates reported by Chow (2001) for an earlier period (1980's and early 1990's). The variables in the outcome equation include the years of Mincer experience, Mincer experience squared, our proxy of ability (we use parental income as the proxy in this paper) and some dummy variables such as the sex, the provinces of residence, the sector and the firm ownership in which he or she works. The propensity score is estimated by a logistic model, with coefficient estimates presented in Table $4 .^{4}$

We use father's education, mother's education, parental income, and the year of birth as determinants of the probability of going to college. The last column of the table is the mean marginal effect for each explanatory variable. Figure 1 shows the density function for the estimated probability of college attendance $(\operatorname{Pr}(S=1))$.

Table 5 and Figure 2 give the results from our semiparametric estimation. We use parental income in the earnings function to control for ability. For details on the procedures used to generate these numbers see Carneiro, Heckman and Vytlacil (2001), whom we follow. Table 5 contains the estimated coefficients for Equations (3a) and (3b) using local linear regression. Figure 2 plots the estimated marginal treatment effect as a function unobserved heterogeneity $u_{s}$, the components in the choice equation. The MTE is declining in $u_{s}$. This implies that people with lower $u_{s}$, i.e. those more likely to go to college according to the decision rule (7), have higher marginal returns to schooling. The people with the highest $u_{s}$, who are least likely going to college, have the lowest average returns. Figure 2 suggests substantial heterogeneity in the return to education for China. The declining MTE implies that matching and conventional $O L S$ and $I V$ methods do not identify any relevant treatment effect in our data. (See Heckman, 2001 or Heckman and Navarro, 2003). It also suggests that the marginal participant in Chinese higher education earns less than the average participant.

Table 6 presents a comparison among various treatment parameters. The average return to 4-year college attendance for a randomly selected person is $43 \%$ (11\% annually) given by $A T E$. The effect of going to college

\footnotetext{
$\operatorname{Pr}(S=1 \mid X)=\frac{\exp \left(\beta^{\prime} X\right)}{1+\exp \left(\beta^{\prime} X\right)}=\Lambda\left(\beta^{\prime} X\right)$

Marginal effects $=\frac{\partial \operatorname{Pr}(S=1 \mid X)}{\partial X}=\Lambda\left(\beta^{\prime} X\right)\left[1-\Lambda\left(\beta^{\prime} X\right)\right] \beta$.
}

${ }^{4}$ The general forms of the logistic model and the marginal effects derived from it are defined as: 
on those who go is $51 \%$, so there is purposive sorting into schooling on the basis of gain (13\% annual). The OLS estimator is downward biased for $A T E$ with only a $29 \%$ return ( $7 \%$ annual). The inconsistent $I V$ estimator is $56 \%$ and is upward biased due to heterogeneity and selection bias (Heckman and Vytlacil derive the exact bias). The Chinese data set show that $I V>A T E>O L S$. The estimated selection bias of $-22 \%$ is very important in estimating the economic return to schooling for China. Persons who go to college would make poor high school graduates. Treatment on the treated (TT ) and treatment on the untreated (TUT ) are $51 \%$ and $36 \%$ respectively. Thus $I V$ is upward biased for $T T$.

The estimated sorting gain is large and positive, suggesting that the principle of comparative advantage is important. The "sorting gain" reported in Table 6 is defined as:

$$
\text { Sorting Gain }=E\left(\beta_{i}-\bar{\beta} \mid X_{i}, S_{i}=1\right)=E\left(\beta_{i} \mid X_{i}, S_{i}=1\right)-\bar{\beta}(X)=T T-A T E
$$

Table 6 and Figure 2 also reveal that the average return to college attendance is high in 2000 for young people in urban areas of the six provinces of China.

Figure 3 plots the estimated weights used to form treatment parameters ATE, TT and TUT. ATE weights MTE evenly. TT overweights the ATE for persons with low values of $u_{s}$ who, ceteris paribus, are more likely to attend college. TUT overweights the ATE for persons with high values of $u_{s}$ who are less likely to attend college. Not surprisingly, in light of the shape of MTE and the shape of the weights, TT $>A T E>T U T$. This is also revealed in the Table 6 . There is substantial heterogeneity among individuals and there is a positive sorting gain and a negative selection bias.

In order to test the importance of introducing a proxy for ability in the wage equation, we exclude parental income from the wage equation and re-estimate the marginal treatment effects. The results are displayed in Figure 4. In this case, the MTE increases in $u_{s}$ and its average value is obviously much higher than that in Figure 2. Therefore, neglecting ability (or its proxy) results in an upward bias for the marginal treatment effect and the estimated return to schooling.

To explore the sensitivity of the estimates to various exclusions and inclusions, we present the estimates shown in Tables 7(a) - 7(d). MTEs are plotted for various specifications of the model controlling (or not controlling) for sectoral choices and for ability (see Figures 5 and 6). 
Our main specification conditions on sectoral choices including the ownership structure of the firm. As is well known, conditioning on sectoral choices in the wage equation is likely to lead to an understatement of the full return to schooling because one benefit of education is that it facilitates choice of sector. When we drop various firm ownership and sectoral indicator variables, estimated returns go up (see Table 7d for estimates deleting all sectoral choice and ownership variables). This is clear from Figure 5. However, the effect of including or excluding these variables is very small on estimated marginal treatment effects. Failing to condition on ability (parental income) raises the estimated return to implausible levels and changes the shape of the estimated MTE. This evidence is consistent with the findings of Carneiro (2002).

\section{Concluding Remarks}

This paper uses newly available micro data to identify the returns to higher education in China. We demonstrate the importance of considering heterogeneity and selection bias. Neglecting these two factors leads to biased and inconsistent estimates such as those obtained using conventional $O L S$ and $I V$ parameters. We demonstrate the importance of proxying for ability in the wage equation to identify returns to education. Excluding it leads to implausibly high estimates of the return to schooling. On the other hand, controlling for sectoral choices barely budges the estimates.

In 2000 , the average return to four-year college attendance is $43 \%$ (on average $11 \%$ annually) for young people in the urban areas of the six provinces. The returns to those going to college are even higher. These estimates are all higher than the conventional $O L S$ estimates of the Mincer model, which in turn are higher than the $O L S$ estimates reported for earlier time periods. They imply that, after 20-plus years of economic reform with market orientation, the average return to education in China has increased substantially when compared to those in the 1980's and early 1990's. 


\section{References}

Bjorklund, A. and R. Moffitt (1987), "The Estimation of Wage Gains and Welfare Gains in Self-Selection Models", Review of Economics and Statistics, 69:42-49.

Carneiro, P. (2002), "Heterogeneity and Selection in the Return to Schooling: Implications for Education Policy Evaluation", Ph.D. Dissertation, University of Chicago.

Carneiro, P. and J. Heckman (2002), "The Evidence on Credit Constraints in Post-Secondary Schooling", Economic Journal, Volume 112, issue 482, pp:705-734.

. (2003), "Human Capital Policy," forthcoming in J. Heckman, A. Krueger, Inequality in America: What Role for Human Capital Policies, Cambridge, MA: MIT Press.

Carneiro, P., J. Heckman and E. Vytlacil (2001), "Estimating the Return to Education When It Varies Among Individuals", Working paper, University of Chicago.

China's Urban Household Income and Expenditure Survey (CUHIES) (2000), National Bureau of Statistics, Urban Socio-Economic Survey Organization.

Chow, G. (2001), China's Economic Transformation. Malden, MA: Blackwell Publishers.

Griliches, Z. (1977), “Estimating the Returns to Schooling: Some Econometric Problems,” Econometrica, Volume 45, number 1, pp. 1-22.

Heckman, J. (1997), “Instrumental Variables: A Study of Implicit Behavioral Assumptions Used in Making Program Evaluations", Journal of Human Resources, 32(3), 441-462. . (2001), "Microdata, Heterogeneity and Econometric Policy Evaluation", Nobel Memorial Lecture in Economic Sciences, Journal of Political Economy, 109(4), 673-748.

Heckman, J., L. Lochner and P. Todd. (2003) "Fifty Years of Mincer Earnings Functions," Unpublished manuscript. University of Chicago. 
Heckman, J. and S. Navarro-Lozano. (2003), "Using Matching, Instrumental Variables and Control Functions to Estimate Economic Choice Models" forthcoming in Review of Economics and Statistics. October.

Heckman, J. and E. Vytlacil (1999), “Local Instrumental Variable and Latent Variable Models for Identifying and Bounding Treatment Effects", Proceedings of the National Academy of Sciences, 96:4730-4734.36. . (2000), "Local Instrumental Variables", in C. Hsiao, K. Morimune, and J. Powells, (eds.), Nonlinear Statistical Modeling: Proceedings of the Thirteenth International Symposium in Economic Theory and Econometrics: Essays in Honor of Takeshi Amemiya, Cambridge: Cambridge University Press, 1-46. . (2001), "Structural Equations, Treatment Effects and Econometric Policy Evaluation", Fisher Schultz Lecture World Congress of the Econometric Society.

National Bureau of Statistics (NBS). (2001), China Labor Statistical Yearbook. Beijing: China Statistics Press.

Navarro-Lozano, S. (2002), "Matching, Selection and the Propensity Score: Evidence from Training in Mexico," Working paper, presented at the Seventh Annual Meeting of LACEA, Madrid, Spain, October. 
Table 1. Average Resident Income of Urban China in 2000

(in RMB yuan)

\begin{tabular}{c|c}
\hline Provinces & Average Resident Income \\
\hline Beijing & 10350 \\
Guangdong & 9762 \\
Zhejiang & 9279 \\
Sichuan & 5894 \\
Liaoning & 5358 \\
Shaanxi & 5124 \\
Average of the six provinces & 7627 \\
China average & 6280 \\
\hline
\end{tabular}

Source: NBS (2001), China Statistical Yearbook on Price \& Urban Household Income and Expenditure Survey 2000,

China Statistics Press, Beijing. 
Table 2. Summary Statistics

\begin{tabular}{|c|c|c|c|c|c|c|}
\hline \multirow{2}{*}{ Variable } & \multicolumn{2}{|c|}{ All $(n=587)$} & \multicolumn{2}{|c|}{ Treated $(n=273)$} & \multicolumn{2}{|c|}{$\begin{array}{l}\text { Untreated } \\
(n=314)\end{array}$} \\
\hline & Mean & $\begin{array}{l}\text { Std. } \\
\text { Err }\end{array}$ & Mean & $\begin{array}{l}\text { Std. } \\
\text { Err }\end{array}$ & Mean & $\begin{array}{l}\text { Std. } \\
\text { Err }\end{array}$ \\
\hline Log Wage & 8.86 & 0.86 & 9.12 & 0.77 & 8.64 & 0.88 \\
\hline Age & 26.25 & 4.72 & 26.48 & 4.14 & 26.06 & 5.16 \\
\hline Years of work experience & 6.41 & 4.92 & 5.83 & 4.47 & 6.91 & 5.23 \\
\hline 4-Year college attendance & 0.47 & 0.50 & 1 & 0 & 0 & 0 \\
\hline Male & 0.56 & 0.50 & 0.54 & 0.50 & 0.59 & 0.49 \\
\hline Lived in Guangdong Province (GD) & 0.18 & 0.39 & 0.19 & 0.39 & 0.18 & 0.38 \\
\hline Lived in Liaoning Province (LN) & 0.28 & 0.45 & 0.30 & 0.46 & 0.27 & 0.44 \\
\hline Lived in Shaanxi Province (SX) & 0.10 & 0.30 & 0.08 & 0.27 & 0.12 & 0.33 \\
\hline Lived in Sichuan Province (SC) & 0.16 & 0.37 & 0.15 & 0.36 & 0.17 & 0.38 \\
\hline Lived in Beijing (BJ) & 0.15 & 0.36 & 0.15 & 0.36 & 0.14 & 0.35 \\
\hline Lived in Zhejiang Province (ZJ) & 0.12 & 0.33 & 0.12 & 0.33 & 0.12 & 0.33 \\
\hline Worked in state owned enterprises (SOEs) & 0.62 & 0.49 & 0.72 & 0.45 & 0.54 & 0.50 \\
\hline Worked in collective-owned firms & 0.08 & 0.27 & 0.04 & 0.20 & 0.11 & 0.32 \\
\hline Worked in joint-venture or foreign owned firms & 0.18 & 0.39 & 0.19 & 0.40 & 0.17 & 0.38 \\
\hline Worked in private owned firms & 0.12 & 0.32 & 0.05 & 0.21 & 0.18 & 0.38 \\
\hline Worked in IND_CON sector* & 0.26 & 0.44 & 0.21 & 0.40 & 0.32 & 0.47 \\
\hline Worked in TRA_COM sector* & 0.03 & 0.17 & 0.03 & 0.17 & 0.03 & 0.18 \\
\hline Worked in HOU_RES sector* & 0.08 & 0.27 & 0.07 & 0.26 & 0.09 & 0.29 \\
\hline Worked in SPO_SOC sector* & 0.22 & 0.41 & 0.16 & 0.36 & 0.27 & 0.45 \\
\hline Worked in CUL_SCI sector* & 0.10 & 0.29 & 0.14 & 0.34 & 0.06 & 0.24 \\
\hline Worked in FIN_INS sector* & 0.11 & 0.32 & 0.09 & 0.28 & 0.13 & 0.34 \\
\hline Worked in GOVERN sector* & 0.03 & 0.16 & 0.04 & 0.20 & 0.02 & 0.13 \\
\hline Worked in OTHER sector* & 0.17 & 0.38 & 0.27 & 0.45 & 0.08 & 0.28 \\
\hline Years of father's education & 11.36 & 3.38 & 12.26 & 3.26 & 10.57 & 3.28 \\
\hline Years of mother's education & 9.90 & 2.99 & 10.41 & 3.31 & 9.46 & 2.60 \\
\hline Parental income (in 1000 yuan) & 21.39 & 16.59 & 24.36 & 15.89 & 18.81 & 16.78 \\
\hline Born before 1964 & 0.03 & 0.17 & 0.02 & 0.15 & 0.04 & 0.20 \\
\hline Born in 1964 & 0.02 & 0.14 & 0.01 & 0.10 & 0.03 & 0.17 \\
\hline Born in 1965 & 0.03 & 0.16 & 0.04 & 0.20 & 0.02 & 0.13 \\
\hline Born in 1966 & 0.02 & 0.14 & 0.03 & 0.16 & 0.02 & 0.13 \\
\hline Born in 1967 & 0.01 & 0.09 & 0.01 & 0.09 & 0.01 & 0.10 \\
\hline Born in 1968 & 0.03 & 0.16 & 0.03 & 0.17 & 0.02 & 0.15 \\
\hline Born in 1969 & 0.03 & 0.17 & 0.03 & 0.16 & 0.04 & 0.18 \\
\hline Born in 1970 & 0.05 & 0.22 & 0.03 & 0.16 & 0.07 & 0.26 \\
\hline Born in 1971 & 0.06 & 0.23 & 0.07 & 0.26 & 0.04 & 0.20 \\
\hline Born in 1972 & 0.05 & 0.22 & 0.05 & 0.22 & 0.05 & 0.21 \\
\hline Born in 1973 & 0.08 & 0.27 & 0.08 & 0.28 & 0.07 & 0.26 \\
\hline Born in 1974 & 0.09 & 0.28 & 0.10 & 0.30 & 0.07 & 0.26 \\
\hline Born in 1975 & 0.09 & 0.28 & 0.11 & 0.31 & 0.07 & 0.26 \\
\hline Born in 1976 & 0.11 & 0.31 & 0.14 & 0.35 & 0.08 & 0.27 \\
\hline Born in 1977 & 0.10 & 0.30 & 0.11 & 0.31 & 0.09 & 0.29 \\
\hline Born in 1978 & 0.10 & 0.30 & 0.11 & 0.31 & 0.09 & 0.29 \\
\hline Born in 1979 & 0.05 & 0.20 & 0.03 & 0.16 & 0.07 & 0.25 \\
\hline Born in 1980 & 0.04 & 0.20 & 0.01 & 0.10 & 0.07 & 0.25 \\
\hline
\end{tabular}

*: IND_CON stands for the sectors of industry, geological exploration \& census, and construction; TRA_COM for sectors of traffic, transportation, post and telecommunication, commerce, catering trade, and material supply; HOU_RES for sectors of housing \& public utility management, and resident service; SPO_SOC for sectors of sanitation, sports, and social welfare; CUL_SCI for sectors of culture, arts, \& education, science, research, and technology services; FIN_INS for sectors of finance and insurance; GOVERN for sectors of state and institutions, party and government mass organization; OTHER for all the other sectors. 
Table 3. Estimated Mincer Model

\begin{tabular}{l|cc|cc}
\hline \multirow{2}{*}{ Variable } & \multicolumn{2}{|c|}{ OLS } & \multicolumn{2}{c}{ IV } \\
\cline { 2 - 5 } & Coefficient & Standard Error & Coefficient & Standard Error \\
\hline Intercept & 8.3189 & 0.1493 & 8.3040 & 0.1552 \\
4-Year's college attendance & 0.2929 & 0.0630 & 0.5609 & 0.1695 \\
Years of work experience & 0.0380 & 0.0194 & 0.0196 & 0.0202 \\
Experience squared & -0.0016 & 0.0010 & -0.0007 & 0.0010 \\
Parental income in 1000 yuan & 0.0117 & 0.0020 & 0.0098 & 0.0023 \\
Male & 0.1537 & 0.0602 & 0.1439 & 0.0607 \\
Lived in Guangdong Province & 0.7543 & 0.1255 & 0.7908 & 0.1267 \\
Lived in Liaoning Province & 0.2693 & 0.1085 & 0.3142 & 0.1092 \\
Lived in Sichuan Province & 0.2278 & 0.1181 & 0.2759 & 0.1192 \\
Lived in Beijing & 0.7246 & 0.1241 & 0.7775 & 0.1256 \\
Lived in Zhejiang Province & 0.6241 & 0.1297 & 0.6739 & 0.1314 \\
Worked in state owned enterprises & -0.3679 & 0.0855 & -0.3873 & 0.0868 \\
Worked in collective-owned firms & -0.4786 & 0.1288 & -0.5890 & 0.1298 \\
Worked in private owned firms & -0.4649 & 0.1179 & -0.5304 & 0.1179 \\
Worked in IND_CON sector* & -0.2793 & 0.0788 & -0.3048 & 0.0792 \\
Worked in TRA_COM sector* & -0.4512 & 0.1762 & -0.4645 & 0.1779 \\
Worked in SPO_SOC sector* & -0.2880 & 0.0900 & -0.3106 & 0.0905 \\
Worked in FIN_INS sector* & -0.3220 & 0.1050 & -0.3327 & 0.1061 \\
\hline
\end{tabular}

*: IND_CON stands for the sectors of industry, geological exploration \& census, and construction; TRA_COM for sectors of traffic, transportation, post and telecommunication, commerce, catering trade, and material supply; SPO_SOC for sectors of sanitation, sports, and social welfare; FIN_INS for sectors of finance and insurance.

\#: Using Propensity score as the instrument for four-year college attendance (Instruments are parental education and year of birth). 
Table 4. Estimated Logit Model For Schooling

\begin{tabular}{|c|c|c|c|}
\hline Variable & Coefficient & Standard Error & $\begin{array}{c}\text { Mean } \\
\text { Marginal Effect }\end{array}$ \\
\hline Intercept & -4.7370 & 0.7305 & - \\
\hline Years of father's education & 0.1017 & 0.0297 & 0.0211 \\
\hline Years of mother's education & 0.0605 & 0.0342 & 0.0126 \\
\hline Parental income in 1000 yuan & 0.0190 & 0.0069 & 0.0040 \\
\hline Born before 1964 & 2.0008 & 0.7969 & 0.4159 \\
\hline Born in 1964 & 1.7285 & 0.9189 & 0.3593 \\
\hline Born in 1965 & 3.3423 & 0.8257 & 0.6947 \\
\hline Born in 1966 & 3.1813 & 0.8552 & 0.6613 \\
\hline Born in 1967 & 1.8455 & 1.1126 & 0.3836 \\
\hline Born in 1968 & 2.9030 & 0.8161 & 0.6034 \\
\hline Born in 1969 & 2.2569 & 0.7941 & 0.4691 \\
\hline Born in 1970 & 1.5076 & 0.7534 & 0.3134 \\
\hline Born in 1971 & 3.0771 & 0.7138 & 0.6396 \\
\hline Born in 1972 & 2.6424 & 0.7183 & 0.5492 \\
\hline Born in 1973 & 2.5395 & 0.6809 & 0.5279 \\
\hline Born in 1974 & 2.7740 & 0.6753 & 0.5766 \\
\hline Born in 1975 & 2.7931 & 0.6763 & 0.5806 \\
\hline Born in 1976 & 2.8634 & 0.6669 & 0.5952 \\
\hline Born in 1977 & 2.5890 & 0.6672 & 0.5381 \\
\hline Born in 1978 & 2.5572 & 0.6656 & 0.5315 \\
\hline Born in 1979 & 1.3631 & 0.7636 & 0.2833 \\
\hline
\end{tabular}


Table 5. Estimated Coefficients from Local Linear Regression

Guassian Kernel, bandwidth $=0.4$

\begin{tabular}{l|cc|cc}
\hline \multirow{2}{*}{ Variable } & \multicolumn{2}{|c|}{ High School } & \multicolumn{2}{c}{ College } \\
\cline { 2 - 5 } Years of work experience & $\gamma_{0}$ & Std. Err. & $\gamma_{1}$ & Std. Err. \\
Experience squared & 0.0360 & 0.0225 & 0.0141 & 0.0278 \\
Parental income in 1000 yuan & -0.0013 & 0.0011 & -0.0009 & 0.0013 \\
Male & 0.0188 & 0.0038 & 0.0077 & 0.0038 \\
Lived in Guangdong Province & 0.1365 & 0.0723 & 0.1913 & 0.0777 \\
Lived in Liaoning Province & 0.5712 & 0.1961 & 0.8853 & 0.1590 \\
Lived in Sichuan Province & 0.1901 & 0.1263 & 0.3929 & 0.1049 \\
Lived in Beijing & 0.2612 & 0.1364 & 0.2296 & 0.1081 \\
Lived in Zhejiang Province & 0.7122 & 0.1695 & 0.7971 & 0.1301 \\
Worked in state owned enterprises & 0.6930 & 0.1551 & 0.5461 & 0.1744 \\
Worked in collective-owned firms & -0.3368 & 0.1188 & -0.4471 & 0.1093 \\
Worked in private owned firms & -0.6060 & 0.2065 & -0.5868 & 0.1771 \\
Worked in IND_CON sector* & -0.4205 & 0.1511 & -0.6256 & 0.1677 \\
Worked in TRA_COM sector* & -0.2297 & 0.0821 & -0.3978 & 0.0990 \\
Worked in SPO_SOC sector* & -0.3527 & 0.1318 & -0.5040 & 0.1557 \\
Worked in FIN_INS sector* & -0.3702 & 0.1282 & -0.3040 & 0.1202 \\
\hline
\end{tabular}

*: IND_CON stands for the sectors of industry, geological exploration \& census, and construction; TRA_COM for sectors of traffic, transportation, post and telecommunication, commerce, catering trade, and material supply; SPO_SOC for sectors of sanitation, sports, and social welfare; FIN_INS for sectors of finance and insurance. 
Table 6. Comparison of Different Parameters

\begin{tabular}{c|c}
\hline Parameter & Estimation \\
\hline OLS & 0.2929 \\
IV* & 0.5609 \\
ATE & 0.4336 \\
TT & 0.5149 \\
TUT & 0.3630 \\
Bias** & -0.1407 \\
Selection Bias*** & -0.2220 \\
Sorting Gain ${ }^{* * * *}$ & 0.0813 \\
\hline
\end{tabular}

* Using propensity score as instrument

** Bias $=$ OLS - ATE

*** Selection Bias $=O L S-T T$

**** Sorting Gain $=T T-A T E$ 
Table 7a. Estimates of Returns to schooling

Including both firms' ownership and sectors' dummies in wage equation

\begin{tabular}{c|c|c}
\hline \multirow{2}{*}{ Parameter } & \multicolumn{2}{|c}{ Annualized } \\
\cline { 2 - 3 } & With parental income & Without parental income \\
\hline \multirow{2}{*}{ OLS } & 0.0732 & 0.0856 \\
IV* & 0.1402 & 0.2192 \\
ATE & 0.1084 & 0.2321 \\
TT & 0.1287 & 0.1909 \\
TUT & 0.0908 & 0.2679 \\
\hline
\end{tabular}

*Using propensity score as the instrument

Table 7b. Estimates of Returns to schooling

Including firms' ownership dummies only in wage equation

\begin{tabular}{c|c|c}
\hline \multirow{2}{*}{ Parameter } & \multicolumn{2}{|c}{ Annualized } \\
\cline { 2 - 3 } & With parental income & Without parental income \\
\hline OLS & 0.0873 & 0.1010 \\
IV* & 0.1777 & 0.2549 \\
ATE & 0.1439 & 0.2659 \\
TT & 0.1588 & 0.2199 \\
TUT & 0.1309 & 0.3059 \\
\hline
\end{tabular}

*Using propensity score as the instrument 
Table 7c. Estimates of Returns to schooling

Including sectors' dummies only in wage equation

\begin{tabular}{c|c|c}
\hline \multirow{2}{*}{ Parameter } & \multicolumn{2}{|c}{ Annualized } \\
\cline { 2 - 3 } & With parental income & Without parental income \\
\hline \multirow{2}{*}{ OLS } & 0.0802 & 0.0920 \\
IV* & 0.1241 & 0.2049 \\
ATE & 0.0960 & 0.2204 \\
TT & 0.1059 & 0.1639 \\
TUT & 0.0874 & 0.2694 \\
\hline
\end{tabular}

*Using propensity score as the instrument

Table 7d. Estimates of Returns to schooling

Excluding both firms' ownership and sectors' dummies in wage equation

\begin{tabular}{c|c|c}
\hline \multirow{2}{*}{ Parameter } & \multicolumn{2}{|c}{ Annualized } \\
\cline { 2 - 3 } & With parental income & Without parental income \\
\hline \multirow{2}{*}{ OLS } & 0.0968 & 0.1109 \\
IV* & 0.1703 & 0.2496 \\
ATE & 0.1420 & 0.2630 \\
TT & 0.1438 & 0.1992 \\
TUT & 0.1404 & 0.3185 \\
\hline
\end{tabular}

*Using propensity score as the instrument 
Figure 1. Density of $P(S=1)$

Urban areas of six provinces of China

From CUHIES 2000

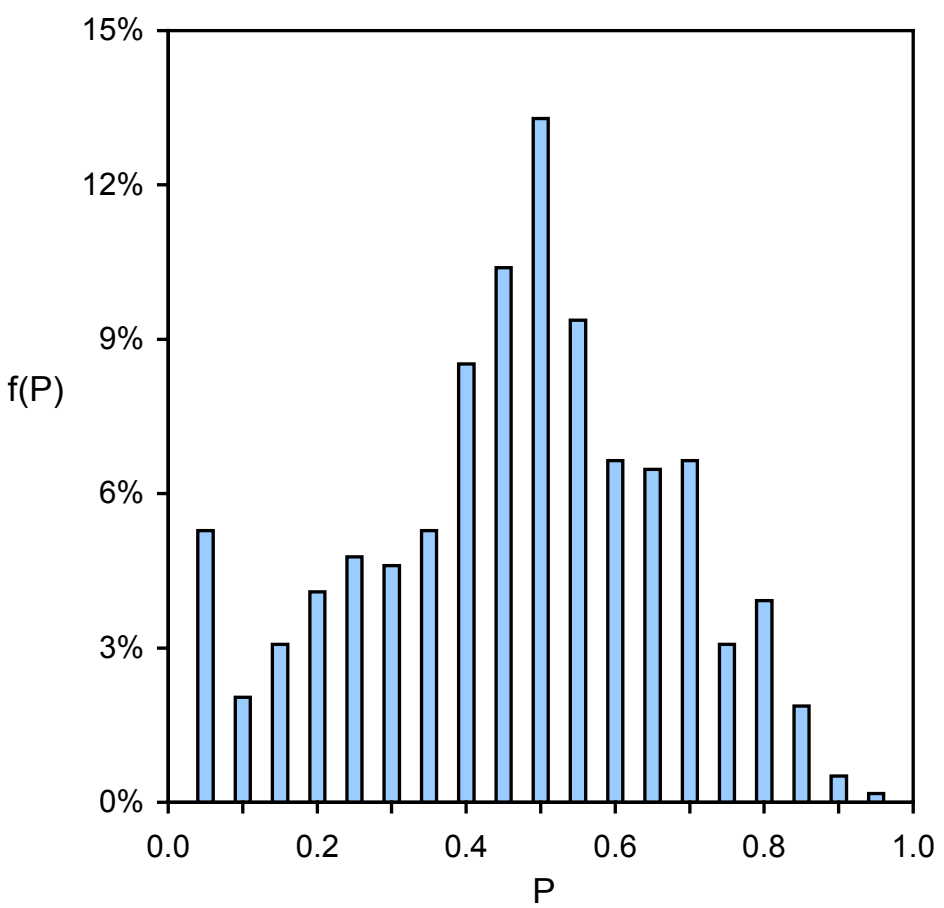


Figure 2. Marginal Treatment Effect

Including parental income as proxy for ability

in wage equation, all ownership and sectoral dummies also included, Bandwidth $=0.4$

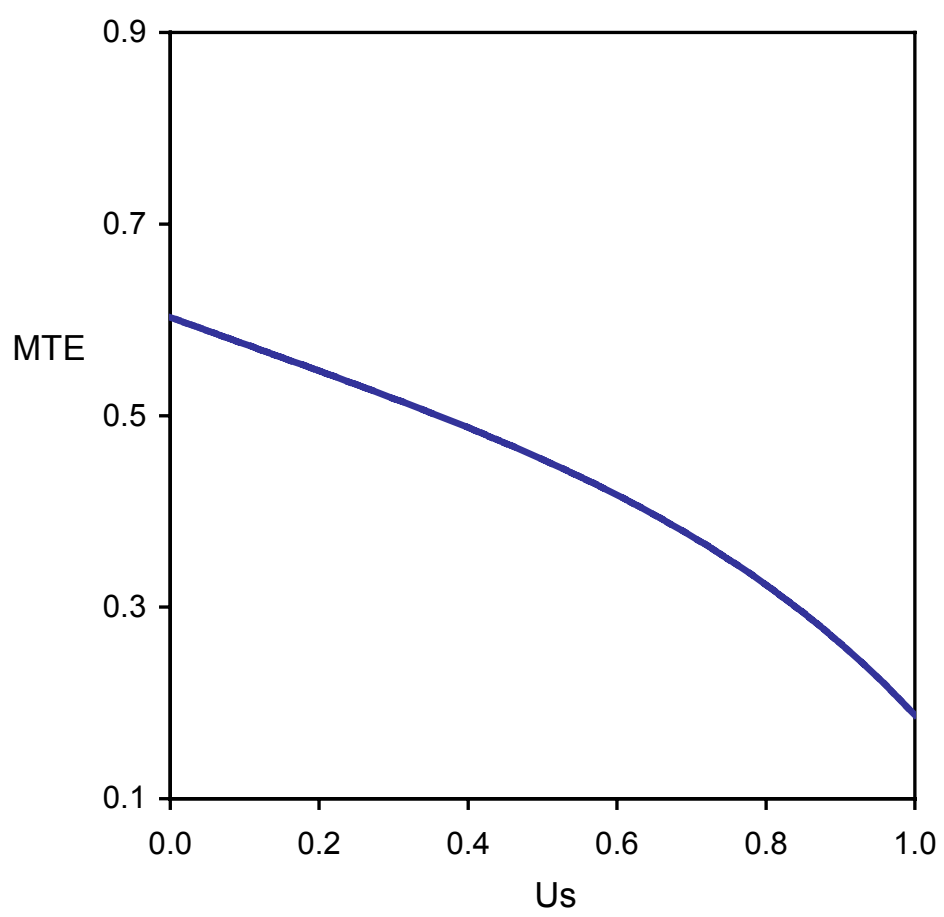


Figure 3. Weights of Treatment Parameters For Main Specifications

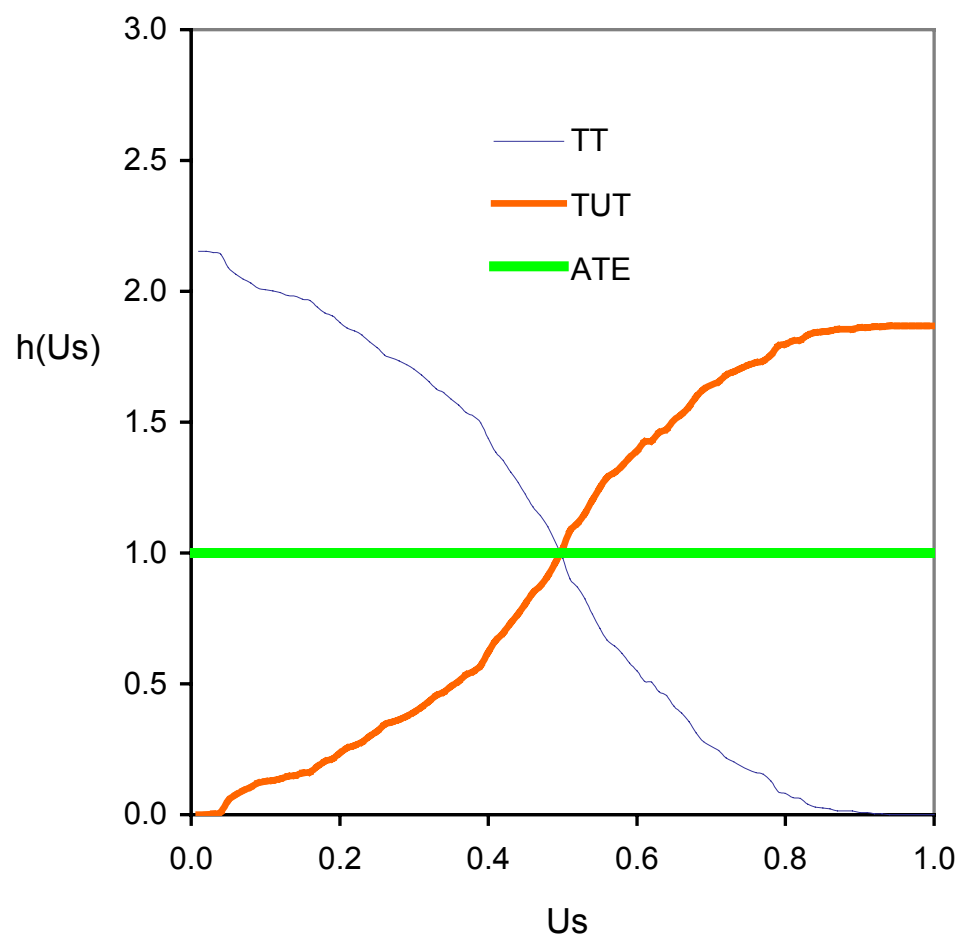


Figure 4. Marginal Treatment Effect

Excluding parental income in wage equation

But all ownership and sectoral dummies included

Bandwidth $=0.3$

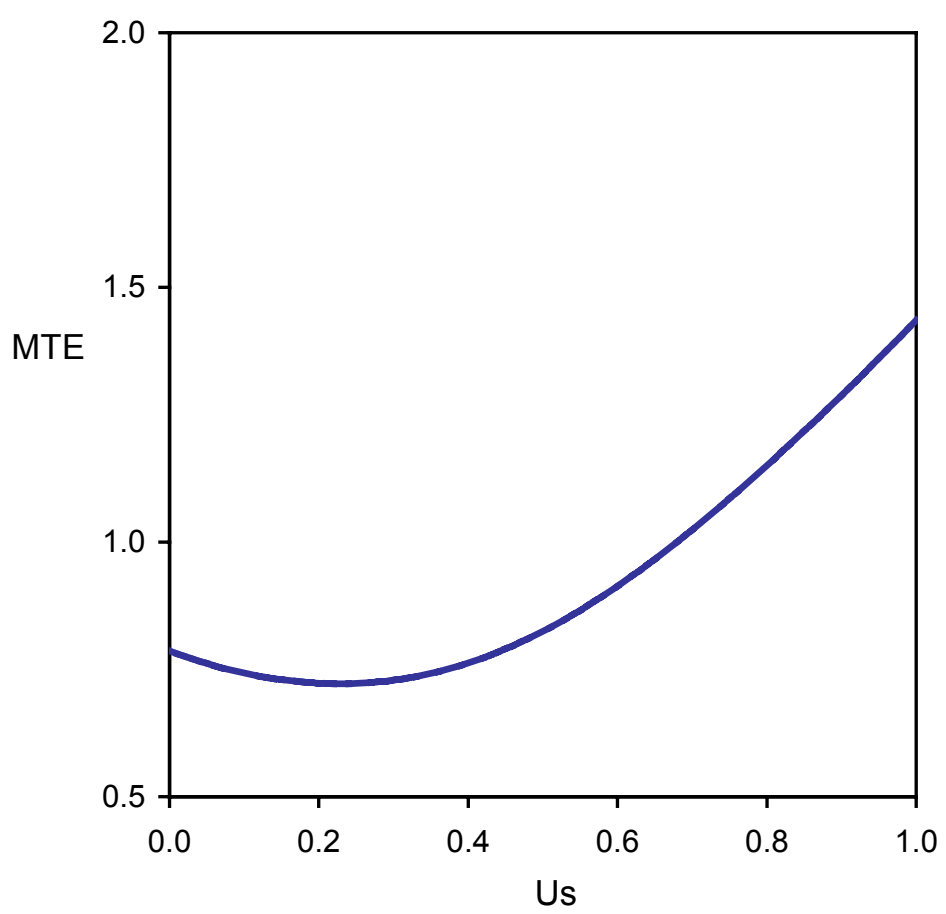


Figure 5. Marginal Treatment Effect All specifications include parental income

in earnings equation, Bandwidth $=0.4$

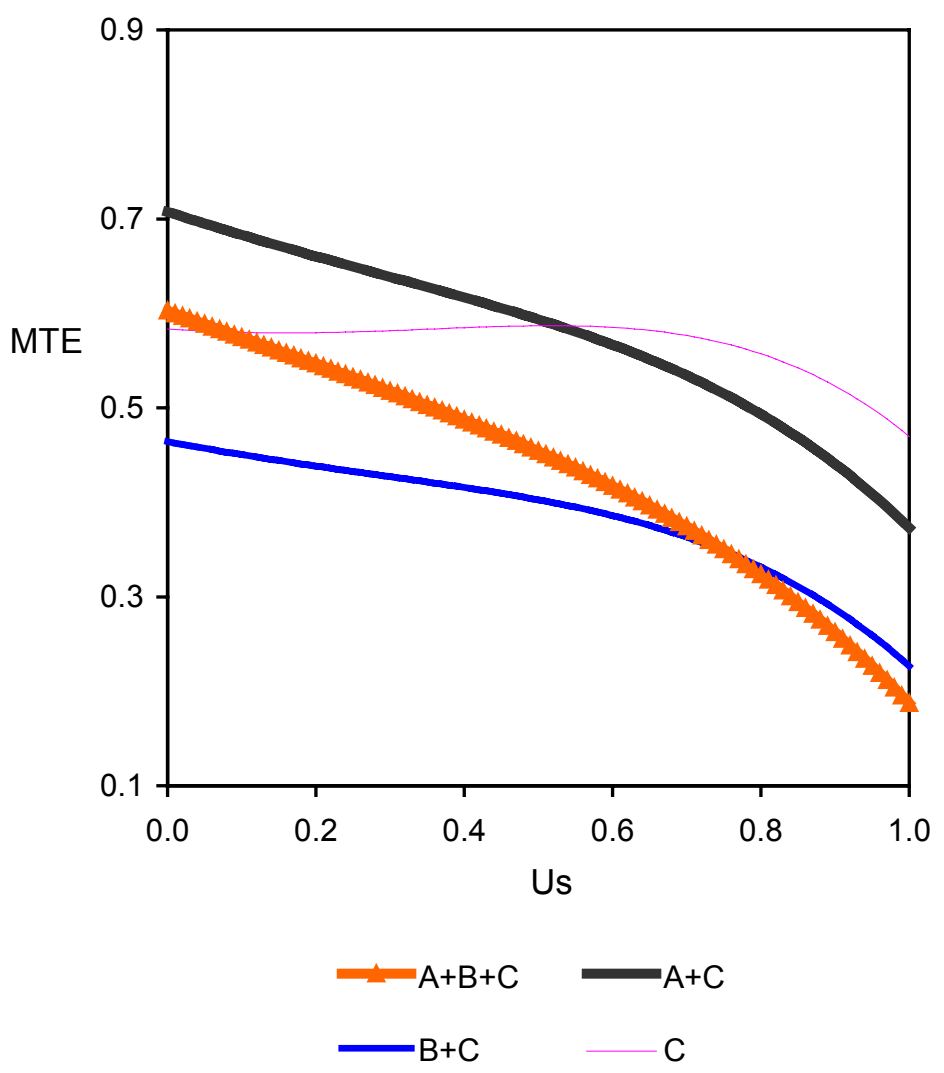

A: with firms' ownership dummies but not sectoral dummies

B: with sectoral dummies but not ownership dummies

C: with parental income as proxy for ability,

no sectoral and ownership dummies 
Figure 6. Marginal Treatment Effect

All specifications exclude parental income

in earnings equation, Bandwidth $=0.3$

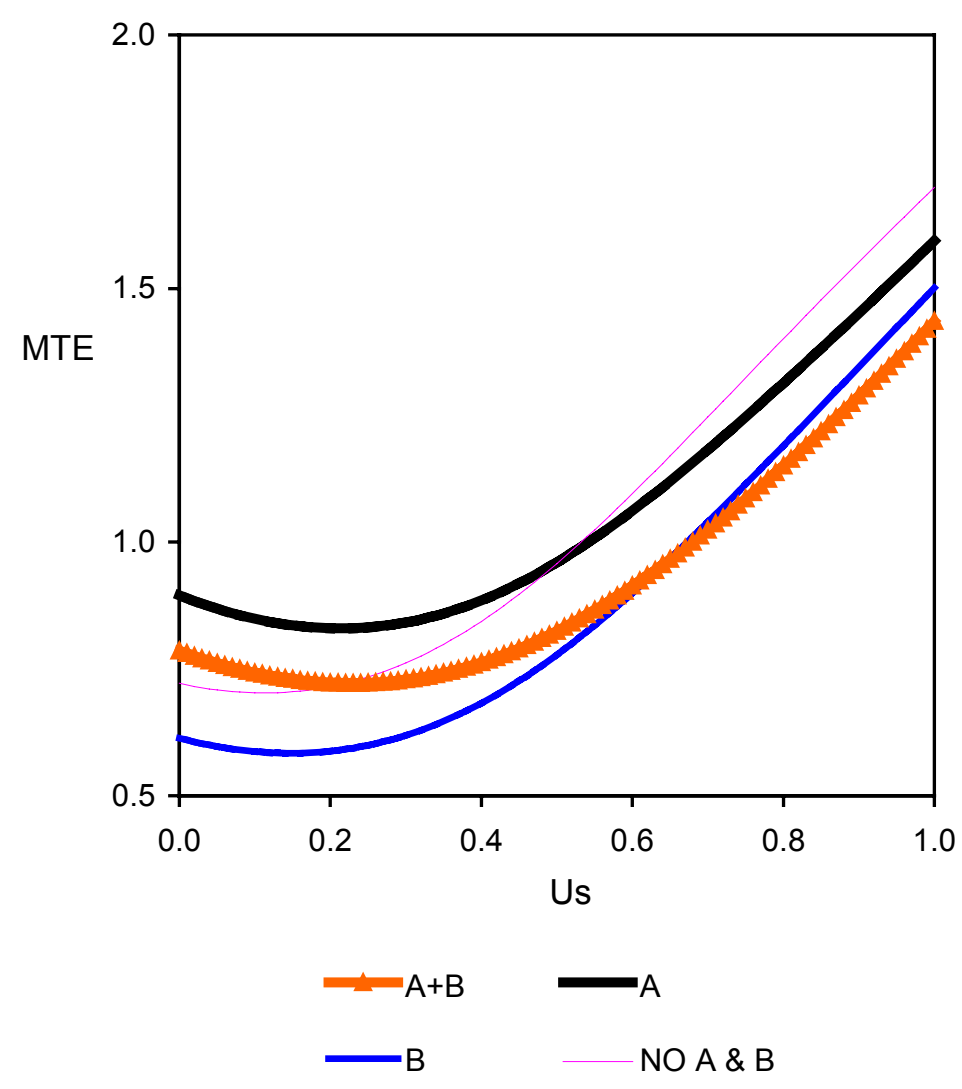
A: only with firms' ownership dummies
B: only with sectoral dummies 


\section{IZA Discussion Papers}

\begin{tabular}{|c|c|c|c|c|}
\hline No. & Author(s) & Title & Area & Date \\
\hline 815 & $\begin{array}{l}\text { A. Aakvik } \\
\text { K. G. Salvanes } \\
\text { K. Vaage }\end{array}$ & $\begin{array}{l}\text { Measuring Heterogeneity in the Returns to } \\
\text { Education in Norway Using Educational Reforms }\end{array}$ & 6 & $07 / 03$ \\
\hline 816 & $\begin{array}{l}\text { T. T. Herbertsson } \\
\text { J. M. Orszag }\end{array}$ & $\begin{array}{l}\text { The Early Retirement Burden: Assessing the } \\
\text { Costs of the Continued Prevalence of Early } \\
\text { Retirement in OECD Countries }\end{array}$ & 3 & $07 / 03$ \\
\hline 817 & $\begin{array}{l}\text { T. M. Andersen } \\
\text { T. T. Herbertsson }\end{array}$ & Measuring Globalization & 2 & $07 / 03$ \\
\hline 818 & J. Pencavel & The Surprising Retreat of Union Britain & 3 & $07 / 03$ \\
\hline 819 & $\begin{array}{l}\text { M. Beine } \\
\text { F. Docquier } \\
\text { H. Rapoport }\end{array}$ & $\begin{array}{l}\text { Brain Drain and LDCs' Growth: Winners and } \\
\text { Losers }\end{array}$ & 1 & $07 / 03$ \\
\hline 820 & $\begin{array}{l}\text { C. M. Cornwell } \\
\text { K. H. Lee } \\
\text { D. B. Mustard }\end{array}$ & $\begin{array}{l}\text { The Effects of Merit-Based Financial Aid on } \\
\text { Course Enrollment, Withdrawal and Completion } \\
\text { in College }\end{array}$ & 6 & $07 / 03$ \\
\hline 821 & $\begin{array}{l}\text { P. Carneiro } \\
\text { J. J. Heckman }\end{array}$ & Human Capital Policy & 6 & $07 / 03$ \\
\hline 822 & $\begin{array}{l}\text { D. Weichselbaumer } \\
\text { R. Winter-Ebmer }\end{array}$ & $\begin{array}{l}\text { The Effects of Competition and Equal Treatment } \\
\text { Laws on the Gender Wage Differential }\end{array}$ & 6 & $07 / 03$ \\
\hline 823 & A. Filippin & Discrimination and Workers' Expectations & 5 & $07 / 03$ \\
\hline 824 & A. Filippin & $\begin{array}{l}\text { Discrimination and Workers' Expectations: } \\
\text { Experimental Evidence }\end{array}$ & 5 & $07 / 03$ \\
\hline 825 & $\begin{array}{l}\text { A. Filippin } \\
\text { A. Ichino }\end{array}$ & $\begin{array}{l}\text { Gender Wage Gap in Expectations and } \\
\text { Realizations }\end{array}$ & 5 & $07 / 03$ \\
\hline 826 & $\begin{array}{l}\text { K. T. Hansen } \\
\text { J. J. Heckman } \\
\text { K. J. Mullen }\end{array}$ & $\begin{array}{l}\text { The Effect of Schooling and Ability on } \\
\text { Achievement Test Scores }\end{array}$ & 6 & 07/03 \\
\hline 827 & $\begin{array}{l}\text { H. Buddelmeyer } \\
\text { E. Skoufias }\end{array}$ & $\begin{array}{l}\text { An Evaluation of the Performance of Regression } \\
\text { Discontinuity Design on PROGRESA }\end{array}$ & 6 & $07 / 03$ \\
\hline 828 & $\begin{array}{l}\text { D. Checchi } \\
\text { T. Jappelli }\end{array}$ & School Choice and Quality & 3 & $07 / 03$ \\
\hline 829 & $\begin{array}{l}\text { J. J. Heckman } \\
\text { X. Li }\end{array}$ & $\begin{array}{l}\text { Selection Bias, Comparative Advantage and } \\
\text { Heterogeneous Returns to Education: Evidence } \\
\text { from China in } 2000\end{array}$ & 6 & $07 / 03$ \\
\hline
\end{tabular}

An updated list of IZA Discussion Papers is available on the center's homepage www.iza.org. 